\title{
Erratum to: Membrane Vesicles: A Common Feature in the Extracellular Matter of Cold-Adapted Antarctic Bacteria
}

\author{
Alina Frias - Angeles Manresa - Eliandre de Oliveira • \\ Carmen López-Iglesias • Elena Mercade
}

Published online: 6 April 2010

(C) Springer Science+Business Media, LLC 2010

\section{Erratum to: Microb Ecol}

DOI 10.1007/s00248-009-9622-9

In the last part of the results before the chapter of Discussion the following number of Table 2 should be changed

"Proteins putatively identified from S. livingstonensis NF22-derived MVs are shown in Table 3".

And Table 3 has to be introduced because it is not present in the article on-line.

The online version of the original article can be found at http://dx.doi. org/10.1007/s00248-009-9622-9.

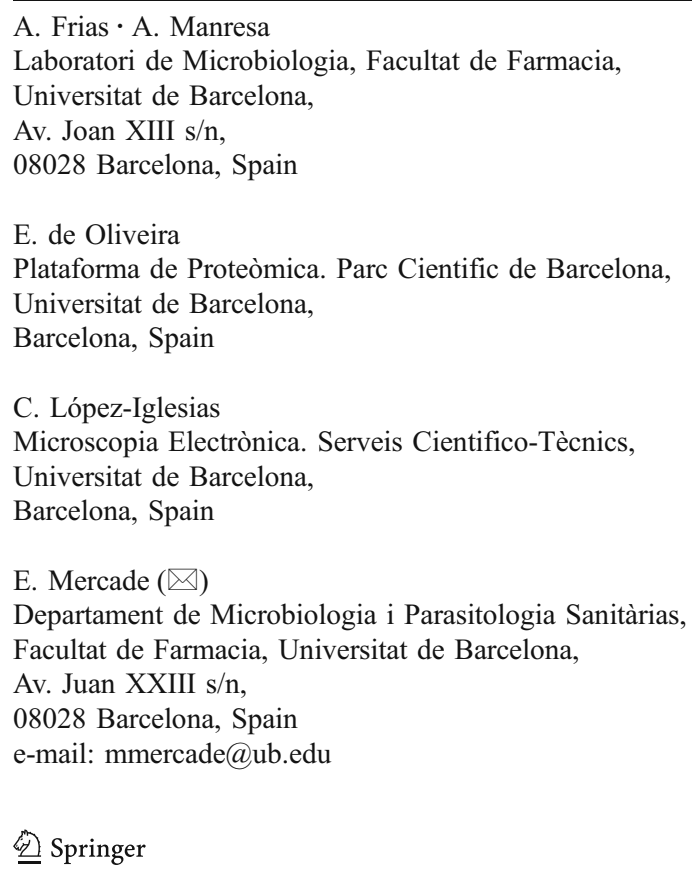


Table 3 Proteins identified by 1D SDS-PAGE from Shewanella livingstonensisNF22

\begin{tabular}{|c|c|c|c|c|c|c|}
\hline${ }^{\mathrm{a}}$ Band no. & Protein annotation & $\begin{array}{l}\text { Protein } \\
\text { Accesión no. }\end{array}$ & $\begin{array}{l}\text { Mowse } \\
\text { score }\end{array}$ & $\begin{array}{l}\text { Coverage } \\
(\%)\end{array}$ & $\begin{array}{l}\text { Peptides } \\
\text { Matches }\end{array}$ & Species \\
\hline \multirow[t]{10}{*}{1} & TonB-dependent receptor & gi|114563586 & $207>53$ & 5 & 8 & $\begin{array}{l}\text { Shewanella frigidimarina } \\
\text { NCIMB } 400\end{array}$ \\
\hline & TonB-dependent receptor & gi|1120598453 & $185>53$ & 3 & 4 & Shewanella sp. W3-18-1 \\
\hline & TonB-dependent receptor & gi|114563641 & $176>53$ & 3 & 4 & $\begin{array}{l}\text { Shewanella frigidimarina } \\
\text { NCIMB } 400\end{array}$ \\
\hline & TonB-dependent receptor & gi|114561796 & $135>53$ & 4 & 3 & $\begin{array}{l}\text { Shewanella frigidimarina } \\
\text { NCIMB } 400\end{array}$ \\
\hline & $\begin{array}{l}\text { Bifunctional UDP-sugar } \\
\text { hydrolase/ 5'-nucleotidase } \\
\text { periplasmic precursor }\end{array}$ & gi|91793491 & $112>53$ & 4 & 2 & $\begin{array}{l}\text { Shewanella denitrificans } \\
\text { OS } 217\end{array}$ \\
\hline & Hypothetical protein Sfri_2571 & gi|114563737 & $101>53$ & 3 & 2 & $\begin{array}{l}\text { Shewanella frigidimarina } \\
\text { NCIMB } 400\end{array}$ \\
\hline & $\begin{array}{l}\text { Bifunctional UDP-sugar } \\
\text { hydrolase/ 5'-nucleotidase } \\
\text { periplasmic precursor }\end{array}$ & gi|15642173 & $94>53$ & 3 & 2 & Vibrio cholerae N16961 \\
\hline & $\begin{array}{l}\text { Bifunctional UDP-sugar } \\
\text { hydrolase/ } 5^{\prime} \text {-nucleotidase } \\
\text { periplasmic precursor }\end{array}$ & gi|149192364 & $94>53$ & 3 & 2 & Vibrio shilonii $\mathrm{AK} 1$ \\
\hline & TonB-dependent receptor & gi|170726911 & $66>53$ & 2 & 2 & $\begin{array}{l}\text { Shewanella woodyi } \\
\text { ATCC } 51908\end{array}$ \\
\hline & Hypothetical protein Sputw3181_1613 & gi| 120598430 & $53>53$ & 2 & 2 & Shewanella sp. W3-18-1 \\
\hline \multirow[t]{7}{*}{2} & $\begin{array}{l}\text { Bifunctional UDP-sugar } \\
\text { hydrolase/ 5'-nucleotidase } \\
\text { periplasmic precursor }\end{array}$ & gi|91793491 & $230>53$ & 7 & 8 & $\begin{array}{l}\text { Shewanella denitrificans } \\
\text { OS } 217\end{array}$ \\
\hline & $\begin{array}{l}\text { Bifunctional UDP-sugar } \\
\text { hydrolase/ 5'-nucleotidase } \\
\text { periplasmic precursor }\end{array}$ & gi|114563480 & $193>53$ & 8 & 5 & $\begin{array}{l}\text { Shewanella frigidimarina } \\
\text { NCIMB } 400\end{array}$ \\
\hline & $\begin{array}{l}\text { Bifunctional UDP-sugar } \\
\text { hydrolase/ 5'-nucleotidase } \\
\text { periplasmic precursor }\end{array}$ & gi|15642173 & $148>53$ & 3 & 3 & Vibrio cholerae N16961 \\
\hline & $\begin{array}{l}\text { Bifunctional UDP-sugar } \\
\text { hydrolase/ 5'-nucleotidase } \\
\text { periplasmic precursor }\end{array}$ & gi|149192364 & $148>53$ & 3 & 3 & Vibrio shilonii AK1 \\
\hline & MscS mechanosensitive ion channel & gi|92115219 & $54>53$ & 1 & 1 & $\begin{array}{l}\text { Chromohalobacter } \\
\text { salexigens DSM } 3043\end{array}$ \\
\hline & UDP-sugar hydrolase & gi|119468684 & $54>53$ & 1 & 1 & $\begin{array}{l}\text { Alteromonadales } \\
\text { bacterium } \text { TW-7 }\end{array}$ \\
\hline & Transporter, putative & gi|26989506 & $53>53$ & 1 & 2 & $\begin{array}{l}\text { Pseudomonas putida } \\
\text { KT2440 }\end{array}$ \\
\hline \multirow[t]{8}{*}{3} & TonB-dependent receptor & gi| 114563586 & $334>52$ & 10 & 9 & $\begin{array}{l}\text { Shewanella frigidimarina } \\
\text { NCIMB } 400\end{array}$ \\
\hline & TonB-dependent receptor & gi|114563641 & $297>52$ & 5 & 6 & $\begin{array}{l}\text { Shewanella frigidimarina } \\
\text { NCIMB } 400\end{array}$ \\
\hline & TonB-dependent receptor & gi|109899987 & $133>52$ & 2 & 2 & $\begin{array}{l}\text { Pseudoalteromonas } \\
\text { atlantica } \mathrm{T} 6 \mathrm{c}\end{array}$ \\
\hline & TonB-dependent receptor & gi|114561796 & $132>52$ & 2 & 2 & $\begin{array}{l}\text { Shewanella frigidimarina } \\
\text { NCIMB } 400\end{array}$ \\
\hline & TonB-dependent receptor & gi|120598453 & $120>52$ & 2 & 4 & Shewanella sp. W3-18-1 \\
\hline & TonB-dependent receptor & gi| 114563610 & $89>52$ & 1 & 1 & $\begin{array}{l}\text { Shewanella frigidimarina } \\
\text { NCIMB } 400\end{array}$ \\
\hline & $\begin{array}{l}\text { Peptidase M16 domain-containing } \\
\text { protein }\end{array}$ & gi|114562249 & $68>52$ & 1 & 1 & $\begin{array}{l}\text { Shewanella frigidimarina } \\
\text { NCIMB } 400\end{array}$ \\
\hline & Outer membrane receptor protein & gi|229240126 & $61>52$ & 1 & 1 & $\begin{array}{l}\text { Chitinophaga pinensis } \\
\text { DSM } 2588\end{array}$ \\
\hline 4 & TonB-dependent siderophore receptor & gi|114565192 & $392>52$ & 15 & 7 & $\begin{array}{l}\text { Shewanella frigidimarina } \\
\text { NCIMB } 400\end{array}$ \\
\hline
\end{tabular}


Table 3 (continued)

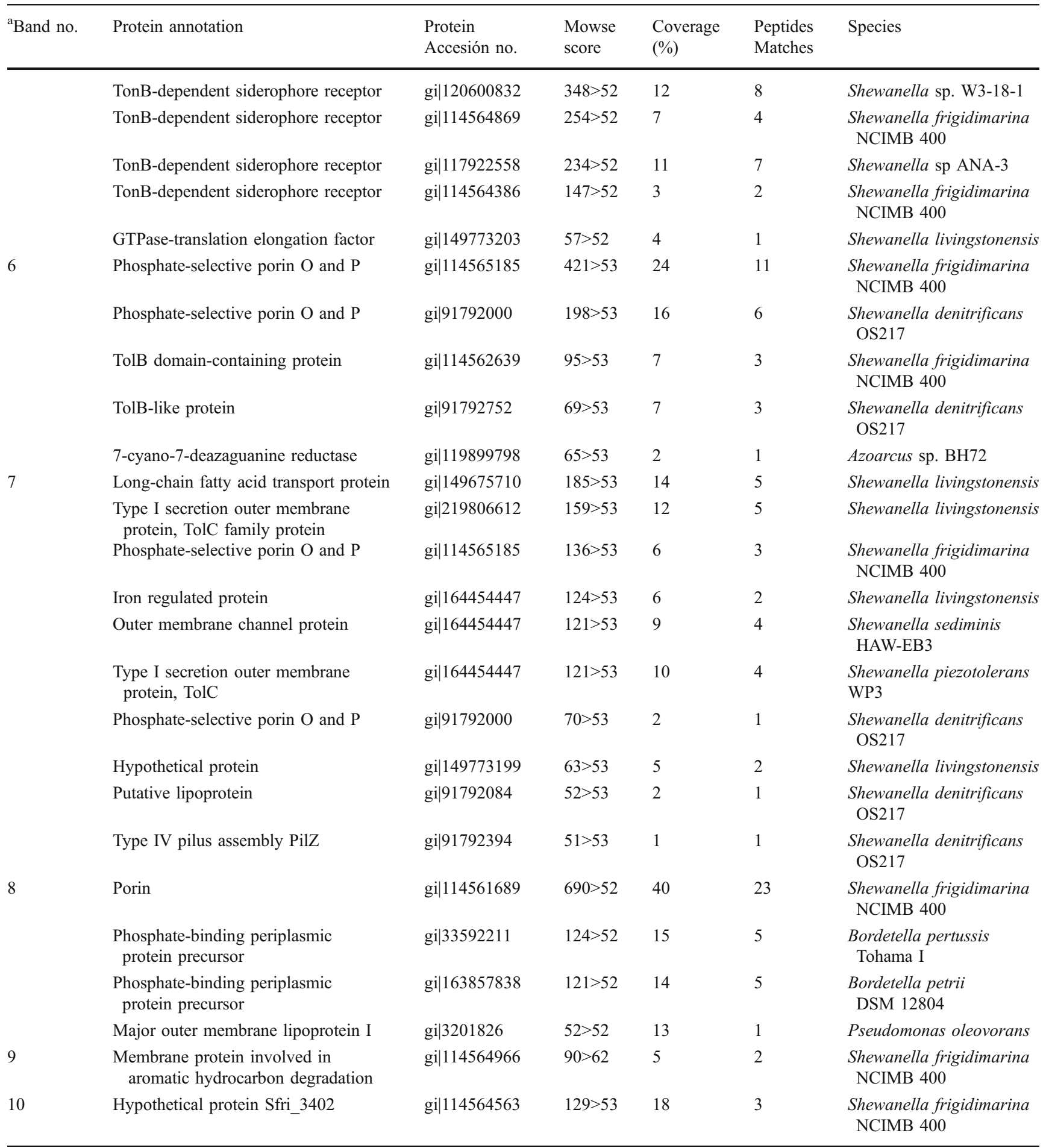

Individual scores $>\mathrm{n}$ indicate identity or extensive homology $(\mathrm{p}<0.05)$

${ }^{\mathrm{a}}$ Band numbers are as indicated in Fig. 4 